\title{
Performance evaluation of different sowing equipment for cultivation of wheat crop (Triticum aestivum $\mathrm{G}$.)
}

Arun Waghmode and Rajneesh Patel

See end of the Paper for authors' affiliation

Correspondence to :

Arun Waghmode

Department Farm Machinery and Power Engineering, Shriram College of Agriculture Engineering (JNKVV) Paniv, Solapur (M.S.) India Email : waghmodemtech@ gmail.com
- ABSTRACT : The performance and evaluation of four sowing equipment treatment was determined for cultivation of wheat crop. Four different treatment such as zero till seed-cumfertilizer drill, Roto till seed-cum-fertilizer drill, 1 xcultivator $+1 \mathrm{x}$ disc harrow + seed-cum- fertilizer drill, $1 \mathrm{x}$ cultivator $+2 \mathrm{x}$ disc harrow + raised bed planter (Aikins and Afuakwa, 2010) all prevailing environmental condition such climatic condition i.e. temperature and relative humidity, physical properties of soil i.e. soil moisture content, bulk density and shear strength, as well as machine and crop parameters were studied before sowing treatment (Benjamin and Cruse, 1987). There are several drills like conventional, zero till, rototill, raised bed planting etc. can be used for sowing wheat. The improved machines not only deliver the desired amount of seed and fertilizer but also save time and energy. The performance of seed drill is improved by manipulating the depth of sowing and thickness of soil cover over the seed as well as pressing the soil cover (Baumgartl and Horn,1991.) The initial bulk density of soil reduced in treatment $T_{1}, T_{2}, T_{3}$ and $T_{4}$ as the soil manipulation occurred. The soil moisture content after sowing decreased in all the treatments at different depths. The highest reduction was observed in treatment $\mathrm{T}_{4}$ due to more tillage operation and used of raised bed planter. Better soil pulverization was observed in case of treatment $\mathrm{T}_{2}$ where seed bed was prepared by rotary tiller. The cone index of soil was increased with depth. It was found to be minimum at different depths in treatment $\mathrm{T}_{4}$ which includes $1 \mathrm{x}$ cultivator followed by $2 \mathrm{x}$ disc harrow then sowing by using raised bed planter. The similar trend was observed even at 100 DAS. The field efficiency was found to be maximum $(77.02 \%)$ in treatment $\mathrm{T}_{1}$ and minimum $(60.91 \%)$ in treatment $\mathrm{T}_{4}$. This is because maneuverability and initial in case of zero till dril. The plant height varied in different treatments till 15DAS, however, at latest age of crop growth. The plant height was near to each others though it was more in treatments $T_{3}$ and $T_{4}$. This is because soil was tilled deeper which probably helped in more root growth. The number of plants/m length, seed emergence was minimum in treatment $\mathrm{T}_{1}$ and similar in other treatment. The plant population was also less in treatment $T_{1}$ and similar in treatment $T_{2}, T_{3}$ and $T_{4}$. It was found more in treatment $\mathrm{T}_{4}$. Length of ear head in all the treatment was almost similar. The weed count was found to be minimum in treatment $\mathrm{T}_{4}$ and maximum in treatment $\mathrm{T}_{1}$ as there was no soil manipulation in treatment $\mathrm{T}_{1}$. The crop cutting yield was minimum (48.3q/ha) in treatment and maximum in treatment $\mathrm{T}_{4}$ $(51.7 \mathrm{q} / \mathrm{ha})$, in treatments $\mathrm{T}_{2}$ and $\mathrm{T}_{3}$ there is slight difference in grain yield. The straw yield was minimum $(57.95 \mathrm{q} / \mathrm{ha})$ in case of treatment $\mathrm{T}_{1}$ probably due to less tillers and less plant population. 1000 grain weight was found similar in all the treatments (Bhattacharyya et al., 2008).

- KEY WORDS : Seed drill, Cultivator, Disc harrow, Planter, Soil properties, Energy, Economics

— HOW TO CITE THIS PAPER : Waghmode, Arun and Patel, Rajneesh (2019). Performance evaluation of different sowing equipment for cultivation of wheat crop (Triticum aestivum G.). Internat. J. Agric. Engg., 12(1) : 53-62, DOI: 10.15740/HAS/IJAE/12.1/53-62. Copyright@ 2019: Hind Agri-Horticultural Society. 